\title{
23. SULFUR, CHLORINE, AND FLUORINE IN GLASS INCLUSIONS IN OLIVINE AND CLINOPYROXENE FROM BASALTIC HYALOCLASTITES REPRESENTING THE GRAN CANARIA SHIELD STAGE AT SITES 953 AND $956^{1}$
}

\author{
Thor H. Hansteen ${ }^{2}$ and Andrey A. Gurenko²
}

\begin{abstract}
Sulfur, chlorine, and fluorine concentrations of primary silicate glass inclusions in olivine and clinopyroxene from basaltic hyaloclastites representing the Gran Canaria shield stage at Sites 953 and 956 were investigated using an electron microprobe. Inclusion compositions corrected for post-entrapment, host-mineral crystallization range from 46.3 to $54.4 \mathrm{wt} \% \mathrm{SiO}_{2}$, and from 5.7 to $10.3 \mathrm{wt} \% \mathrm{MgO}$. Significant spread in S and $\mathrm{Cl}$ values (200-2390 ppm S, and 120-870 ppm Cl) and the lack of correlation between $\mathrm{S}$ and $\mathrm{Cl}$ with $\mathrm{MgO}$ and $\mathrm{P}$ suggest partial degassing of the magmas prior to eruption. $\mathrm{F}$ was not degassed during magma evolution and thus can be used to discuss magma source compositions. The lack of correlation between $\mathrm{SiO}_{2}$ and $\mathrm{F}$ in the calculated parental magmas suggests that pressure is not likely to have exerted the main control on volatile contents. A source with heterogeneous $\mathrm{F}$ contents is inferred. The occurrence of $\mathrm{S}^{2-}$, as the only detectable $\mathrm{S}$ species in the glass inclusions, suggests crystallization conditions with $f_{2}$ levels at or below the Ni-NiO (NNO) buffer.
\end{abstract}

\section{INTRODUCTION}

One purpose of Leg 157 was to recover samples from the submarine and early shield stages of Gran Canaria and to tie these into the evolutionary history of the island. Because the seamount and shield stages of an oceanic island represent the highest magma production and eruption rates during its history (e.g., Schmincke et al., 1995), investigations of melt generation and evolution during these early phases are of essential importance for better understanding the origin of oceanic intraplate volcanism.

During Leg 157, at Sites 953 through 956, core samples covering practically the complete time interval from the Quaternary to middle Miocene, were recovered from the volcaniclastic apron north and south of Gran Canaria (Schmincke, Weaver, Firth et al., 1995; Fig. 1). Samples recovered from Sites 953 and 956 include Miocene sequences corresponding to the shield stage of Gran Canaria. Hyaloclastites of Miocene age, recovered during Leg 157, are described in detail by Schmincke and Segschneider (Chap. 12, this volume). We have studied the same 13 samples of basaltic hyaloclastic tuffs and lapillistones from Sites 953 and 956 as Gurenko et al. (Chap. 22, this volume; Table 1). Sample descriptions, compositions of liquidus minerals and fluid inclusions, and the major and trace element compositions of glass inclusions are given in that paper. The samples are strongly to moderately altered, but contain optically fresh phenocrysts of clinopyroxene and, more rarely, optically fresh olivine cores; both minerals contain abundant primary glass, crystal, and fluid inclusions.

This paper focuses on the halogen and sulfur concentrations of primary glass inclusions in these minerals. The abundance and evolution of such volatile and incompatible elements are used to make inferrences about the mantle source during the shield stage of Gran Canaria, and to describe the degassing behavior at depth in the lithosphere and during eruption.

${ }^{1}$ Weaver, P.P.E., Schmincke, H.-U., Firth, J.V., and Duffield, W. (Eds.), 1998. Proc. ODP Sci. Results, 157: College Station, TX (Ocean Drilling Program).

${ }^{2}$ GEOMAR Forschungszentrum, Wischhofstraße 1-3, D-24148 Kiel, Federal Republic of Germany. thansteen@ geomar.de

\section{ANALYTICAL METHODS \\ Electron Microprobe Analysis}

Fluorine, chlorine, sulfur, and phosphorous were analyzed as trace elements with a Cameca SX-50 electron microprobe at Research Center for Marine Geosciences, Federal Republic of Germany (GEOMAR), using an acceleration potential of $15 \mathrm{kV}$ and a beam current of 20-25 nA. The electron beam was rastered between $3 \mu \mathrm{m}$ $\times 4 \mu \mathrm{m}$ and $10 \mu \mathrm{m} \times 12 \mu \mathrm{m}$, and peak counting times were $60 \mathrm{~s}$. The standards used were chalcopyrite for S, scapolite USNM R6600-1 for

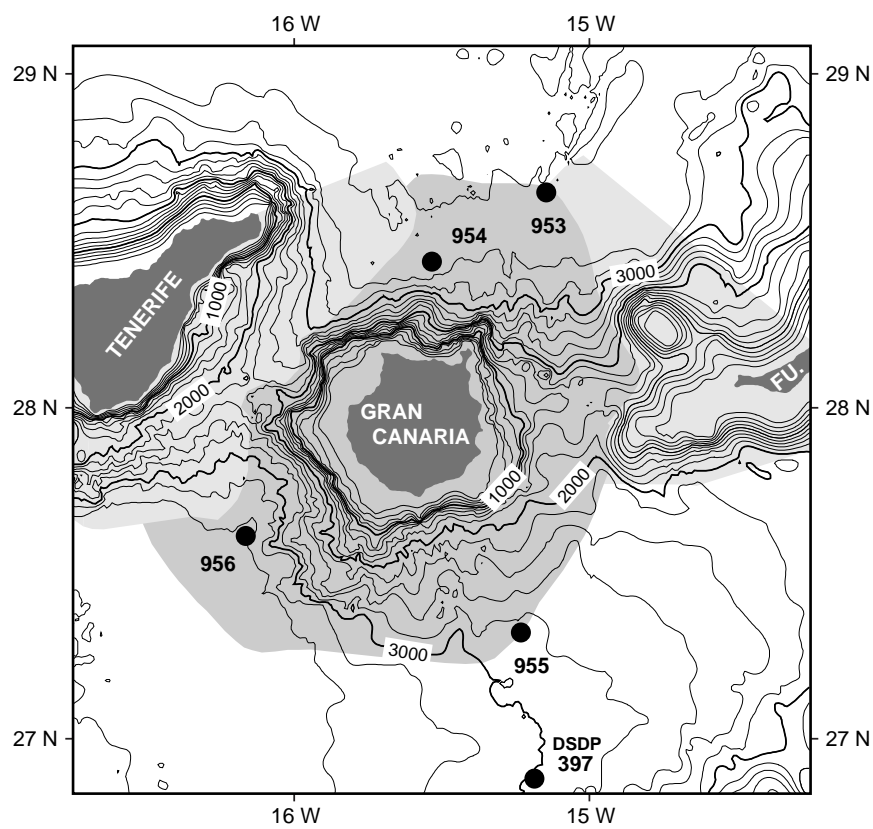

Figure 1. Schematic map showing locations of Site 953 through 956 in relation to the Canary Islands (after Funck, 1996). Fields are seismically defined volcaniclastic aprons of Fuerteventura, Gran Canaria, and Tenerife. 
T.H. HANSTEEN, A.A. GURENKO

Table 1. Volatile compositions of selected major element data of melt inclusions, and calculated volatile compositions of the trapped melts.

\begin{tabular}{|c|c|c|c|c|c|c|c|c|c|c|c|}
\hline Sample & Phase & $\mathrm{SiO}_{2}$ & $\mathrm{MgO}$ & $\mathrm{K}_{2} \mathrm{O}$ & $\mathrm{Cl}$ & $\mathrm{F}$ & $S$ & $\mathrm{P}$ & $\mathrm{Mg} \#, \mathrm{Fo}$ & $\mathrm{Ol}_{\text {add }}$ & $\mathrm{Cpx}_{\mathrm{add}}$ \\
\hline \multicolumn{12}{|l|}{$\begin{array}{l}157-953 \mathrm{C}- \\
82 \mathrm{R}-1,52-82\end{array}$} \\
\hline $57 \mathrm{a}$ & $\begin{array}{l}\mathrm{gl} \\
\mathrm{mlt} \\
\mathrm{cpx}\end{array}$ & $\begin{array}{l}45.63 \\
47.4 \\
48.47\end{array}$ & $\begin{array}{c}5.24 \\
6.7 \\
14.49\end{array}$ & $\begin{array}{l}2.05 \\
1.9 \\
\text { ND }\end{array}$ & $\begin{array}{c}0.057 \\
0.051 \\
\text { ND }\end{array}$ & $\begin{array}{c}0.224 \\
0.199 \\
\text { ND }\end{array}$ & $\begin{array}{c}0.103 \\
0.092 \\
\text { ND }\end{array}$ & $\begin{array}{c}0.333 \\
0.295 \\
\text { ND }\end{array}$ & $\begin{array}{l}0.439 \\
0.548 \\
0.797\end{array}$ & $\begin{array}{l}\overline{0} \\
-\end{array}$ & $\begin{array}{l}\overline{11.3} \\
-\end{array}$ \\
\hline \multicolumn{12}{|l|}{$\begin{array}{l}157-953 \mathrm{C}- \\
82 \mathrm{R}-1,94-103\end{array}$} \\
\hline 68 & $\begin{array}{l}\mathrm{gl} \\
\mathrm{mlt} \\
\mathrm{cpx}\end{array}$ & $\begin{array}{l}43.61 \\
48.4 \\
52.07\end{array}$ & $\begin{array}{c}5.39 \\
10.2 \\
16.96\end{array}$ & $\begin{array}{l}1.41 \\
0.9 \\
\text { ND }\end{array}$ & $\begin{array}{c}0.085 \\
0.051 \\
\text { ND }\end{array}$ & $\begin{array}{c}0.204 \\
0.123 \\
\text { ND }\end{array}$ & $\begin{array}{c}0.196 \\
0.118 \\
\text { ND }\end{array}$ & $\begin{array}{c}0.292 \\
0.176 \\
\text { ND }\end{array}$ & $\begin{array}{l}0.408 \\
0.653 \\
0.879\end{array}$ & $\overline{0}$ & $\begin{array}{l}\overline{39.8} \\
-\end{array}$ \\
\hline \multicolumn{12}{|l|}{$\begin{array}{l}157-953 \mathrm{C}- \\
83 \mathrm{R}-7,0-12\end{array}$} \\
\hline $47 \mathrm{a}$ & $\begin{array}{l}\mathrm{gl} \\
\mathrm{mlt}\end{array}$ & $\begin{array}{l}49.93 \\
50.7\end{array}$ & $\begin{array}{c}5.2 \\
8.3\end{array}$ & $\begin{array}{l}0.87 \\
0.7\end{array}$ & $\begin{array}{l}0.033 \\
0.025\end{array}$ & $\begin{array}{l}0.161 \\
0.121\end{array}$ & $\begin{array}{l}0.022 \\
0.016\end{array}$ & $\begin{array}{l}0.189 \\
0.143\end{array}$ & $\begin{array}{l}0.422 \\
0.603\end{array}$ & $\overline{0}$ & $\overline{24.6}$ \\
\hline \multirow[t]{2}{*}{$47 \mathrm{~b}$} & $\begin{array}{l}\mathrm{cpx} \\
\mathrm{gl}\end{array}$ & $\begin{array}{l}50.6 \\
49.11\end{array}$ & $\begin{array}{r}17.39 \\
4.67\end{array}$ & $\begin{array}{l}\text { ND } \\
0.98\end{array}$ & $\begin{array}{l}\mathrm{ND} \\
0.032\end{array}$ & $\begin{array}{l}\text { ND } \\
0.176\end{array}$ & $\begin{array}{l}\text { ND } \\
0.020\end{array}$ & ND & $\begin{array}{l}0.842 \\
0.392\end{array}$ & - & $\overline{-}$ \\
\hline & $\begin{array}{l}\mathrm{mlt} \\
\mathrm{cpx}\end{array}$ & $\begin{array}{l}50.1 \\
49.73\end{array}$ & $\begin{array}{c}8 \\
16.64\end{array}$ & $\begin{array}{l}0.7 \\
\text { ND }\end{array}$ & $\begin{array}{l}0.023 \\
\text { ND }\end{array}$ & $\begin{array}{l}0.13 \\
\text { ND }\end{array}$ & $\begin{array}{l}0.014 \\
\text { ND }\end{array}$ & $\begin{array}{l}0.162 \\
\text { ND }\end{array}$ & $\begin{array}{l}0.587 \\
0.83\end{array}$ & $\underline{0}$ & 25.9 \\
\hline \multicolumn{12}{|l|}{$\begin{array}{l}157-953 \mathrm{C}- \\
89 \mathrm{R}-1,0-13\end{array}$} \\
\hline 26 & $\begin{array}{l}\mathrm{gl} \\
\mathrm{mlt} \\
\mathrm{cpx}\end{array}$ & $\begin{array}{l}48.26 \\
49.3 \\
49.84\end{array}$ & $\begin{array}{c}6.07 \\
7.7 \\
16.04\end{array}$ & $\begin{array}{l}1.09 \\
1 \\
\text { ND }\end{array}$ & $\begin{array}{l}0.032 \\
0.028 \\
\text { ND }\end{array}$ & $\begin{array}{c}0.141 \\
0.122 \\
\text { ND }\end{array}$ & $\begin{array}{c}0.029 \\
0.025 \\
\text { ND }\end{array}$ & $\begin{array}{l}0.231 \\
0.2 \\
\text { ND }\end{array}$ & $\begin{array}{l}0.489 \\
0.601 \\
0.838\end{array}$ & $\overline{0}$ & $\overline{13.7}$ \\
\hline \multicolumn{12}{|l|}{$\begin{array}{l}157-953 \mathrm{C}- \\
90 \mathrm{R}-1,82-101\end{array}$} \\
\hline 14 & $\begin{array}{l}\text { gl-1 } \\
\text { mlt-1 }\end{array}$ & $\begin{array}{l}47.42 \\
48.8\end{array}$ & $\begin{array}{l}5.79 \\
7.6\end{array}$ & $\begin{array}{l}0.92 \\
0.8\end{array}$ & $\begin{array}{l}0.027 \\
0.023\end{array}$ & $\begin{array}{l}0.179 \\
0.152\end{array}$ & $\begin{array}{l}\text { ND } \\
\text { ND }\end{array}$ & $\begin{array}{l}0.220 \\
0.187\end{array}$ & $\begin{array}{l}0.461 \\
0.582\end{array}$ & $\overline{0}$ & $\overline{14.9}$ \\
\hline $14 b$ & $\begin{array}{l}\text { gl-2 } \\
\text { mlt-2 } \\
\text { cpx }\end{array}$ & $\begin{array}{l}47.18 \\
48.4 \\
49.64\end{array}$ & $\begin{array}{c}6.09 \\
7.8 \\
15.89\end{array}$ & $\begin{array}{l}0.9 \\
0.8 \\
\text { ND }\end{array}$ & $\begin{array}{c}0.018 \\
0.015 \\
\text { ND }\end{array}$ & $\begin{array}{c}0.213 \\
0.182 \\
\text { ND }\end{array}$ & $\begin{array}{l}\text { ND } \\
\text { ND } \\
\text { ND }\end{array}$ & $\begin{array}{c}0.202 \\
0.173 \\
\text { ND }\end{array}$ & $\begin{array}{l}0.464 \\
0.581 \\
0.824\end{array}$ & $\overline{0}$ & $\overline{14.4}$ \\
\hline 16 & $\begin{array}{l}\mathrm{gl} \\
\mathrm{mlt} \\
\mathrm{cpx}\end{array}$ & $\begin{array}{l}46.9 \\
48.4 \\
48.64\end{array}$ & $\begin{array}{c}5.08 \\
7.9 \\
15.98\end{array}$ & $\begin{array}{l}1.09 \\
0.9 \\
\text { ND }\end{array}$ & $\begin{array}{l}0.030 \\
0.023 \\
\text { ND }\end{array}$ & $\begin{array}{l}0.195 \\
0.152 \\
\text { ND }\end{array}$ & $\begin{array}{l}0.023 \\
0.018 \\
\text { ND }\end{array}$ & $\begin{array}{l}0.232 \\
0.18 \\
\text { ND }\end{array}$ & $\begin{array}{l}0.399 \\
0.569 \\
0.815\end{array}$ & $\overline{0}$ & $\overline{22.3}$ \\
\hline $\begin{array}{l}157-953 \mathrm{C}- \\
93 \mathrm{R}-6,45-55\end{array}$ & & & & & & & & & & & \\
\hline 4 & $\begin{array}{l}\mathrm{gl} \\
\mathrm{mlt}\end{array}$ & $\begin{array}{l}49.44 \\
49.8\end{array}$ & $\begin{array}{l}6.16 \\
6.8\end{array}$ & $\begin{array}{l}1.14 \\
1.1\end{array}$ & $\begin{array}{l}0.030 \\
0.028\end{array}$ & $\begin{array}{l}0.160 \\
0.151\end{array}$ & $\begin{array}{l}0.014 \\
0.013\end{array}$ & $\begin{array}{l}0.273 \\
0.257\end{array}$ & $\begin{array}{l}0.5 \\
0.575\end{array}$ & $\overline{0}$ & $\overline{5.6}$ \\
\hline & $\mathrm{cpx}$ & 50.39 & 16.09 & ND & ND & ND & ND & ND & 81.5 & - & - \\
\hline 14 & $\begin{array}{l}\mathrm{gl} \\
\mathrm{mlt}\end{array}$ & $\begin{array}{l}50.31 \\
49\end{array}$ & $\begin{array}{l}2.79 \\
7.1\end{array}$ & $\begin{array}{l}1.08 \\
0.9\end{array}$ & $\begin{array}{l}0.029 \\
0.025\end{array}$ & $\begin{array}{l}0.174 \\
0.15\end{array}$ & $\begin{array}{l}0.051 \\
0.044\end{array}$ & $\begin{array}{l}0.285 \\
0.246\end{array}$ & $\begin{array}{l}0.344 \\
0.585\end{array}$ & $\overline{11}$ & $\overline{2.5}$ \\
\hline & ol & 39.04 & 42.59 & ND & ND & ND & ND & ND & 81.4 & - & - \\
\hline 16 & gl-1 & 50.67 & 3.15 & 1.22 & 0.028 & 0.158 & 0.028 & 0.280 & 0.362 & - & - \\
\hline & mlt-1 & 49.6 & 6.9 & 1.1 & 0.024 & 0.137 & 0.024 & 0.244 & 0.581 & 9.1 & 3.9 \\
\hline $16 b$ & gl-2 & 49.64 & 2.84 & 1.12 & 0.026 & 0.175 & 0.031 & 0.285 & 0.34 & $\overline{11}$ & - \\
\hline & $\begin{array}{l}\text { mlt-2 } \\
\text { ol }\end{array}$ & $\begin{array}{l}48.4 \\
38.85\end{array}$ & 42.35 & 1 & $\begin{array}{l}0.023 \\
\text { ND }\end{array}$ & $\begin{array}{l}0.152 \\
\text { ND }\end{array}$ & $\begin{array}{l}0.027 \\
\text { ND }\end{array}$ & $\begin{array}{l}0.248 \\
\text { ND }\end{array}$ & $\begin{array}{l}0.579 \\
81\end{array}$ & 11.2 & 1.9 \\
\hline 19 & $\mathrm{gl}$ & 50.46 & 2.96 & 1.19 & 0.028 & 0.206 & 0.035 & 0.315 & 0.334 & - & - \\
\hline & mlt & 49.8 & 7.2 & 0.9 & 0.022 & 0.162 & 0.028 & 0.248 & 0.587 & 6.5 & 14.8 \\
\hline & ol & 38.16 & 42.32 & ND & ND & ND & ND & ND & 81.2 & - & - \\
\hline 22 & $\mathrm{gl}$ & 50.34 & 3.43 & 1.13 & 0.024 & 0.152 & 0.072 & 0.275 & 0.384 & - & - \\
\hline & mlt & 49.5 & 7.3 & 1 & 0.021 & 0.13 & 0.062 & 0.237 & 0.593 & 8.8 & 5.2 \\
\hline & ol & 39.13 & 43.12 & ND & ND & ND & ND & ND & 81.9 & - & - \\
\hline 24 & $\mathrm{gl}$ & 50.96 & 3.18 & 1.1 & 0.028 & 0.177 & 0.088 & 0.269 & 0.375 & - & - \\
\hline & mlt & 49.7 & 7 & 1 & 0.025 & 0.156 & 0.078 & 0.237 & 0.589 & 9.9 & 2 \\
\hline & ol & 39.06 & 42.83 & ND & ND & ND & ND & ND & 81.6 & - & - \\
\hline 25 & $\mathrm{gl}$ & 50.17 & 2.57 & 1.14 & 0.046 & 0.177 & 0.089 & 0.280 & 0.306 & - & - \\
\hline & mlt & 49.2 & 7.4 & 0.9 & 0.037 & 0.139 & 0.07 & 0.221 & 0.585 & 9.5 & 11.7 \\
\hline & ol & 38.78 & 42.42 & ND & ND & ND & ND & ND & 81.1 & - & - \\
\hline 35 & $\mathrm{gl}$ & 50.17 & 3.92 & 1.27 & 0.028 & 0.165 & 0.025 & 0.290 & 0.416 & - & - \\
\hline & mlt & 49.6 & 6.8 & 1.1 & 0.025 & 0.147 & 0.022 & 0.258 & 0.587 & 5.9 & 5.3 \\
\hline & ol & 39.11 & 42.75 & ND & ND & ND & ND & ND & 81.6 & - & - \\
\hline 37 & gl-1 & 49.58 & 3.42 & 1.13 & 0.036 & 0.175 & 0.019 & 0.287 & 0.372 & - & - \\
\hline & mlt-1 & 48.9 & 7.3 & 1 & 0.031 & 0.149 & 0.016 & 0.245 & 0.586 & 8.6 & 6 \\
\hline $37 \mathrm{~b}$ & gl-2 & 49.96 & 2.82 & 1.05 & 0.025 & 0.192 & 0.021 & 0.253 & 0.339 & - & - \\
\hline & mlt-2 & 48.8 & 7.1 & 0.9 & 0.021 & 0.166 & 0.018 & 0.219 & 0.581 & 11.6 & 1.5 \\
\hline & ol & 38.55 & 42.39 & ND & ND & ND & ND & ND & 81.4 & - & - \\
\hline 40 & gl-1 & 50.16 & 2.46 & 1.24 & 0.025 & 0.179 & 0.022 & 0.286 & 0.319 & - & - \\
\hline & mlt-1 & 49.2 & 6.3 & 1.1 & 0.022 & 0.157 & 0.019 & 0.252 & 0.569 & 10.4 & 1.5 \\
\hline $40 \mathrm{~b}$ & gl-2 & 50.01 & 2.76 & 1.15 & 0.019 & 0.149 & 0.053 & 0.278 & 0.328 & - & - \\
\hline & mlt-2 & 48.9 & 6.7 & 1 & 0.017 & 0.131 & 0.047 & 0.244 & 0.569 & 10.5 & 1.7 \\
\hline & ol & 38.74 & 41.73 & ND & ND & ND & ND & ND & 80.1 & - & - \\
\hline 43 & $\mathrm{gl}$ & 49.35 & 3.24 & 1.1 & 0.036 & 0.174 & 0.131 & 0.324 & 0.388 & - & - \\
\hline & mlt & 48.6 & 7.8 & 1 & 0.031 & 0.148 & 0.111 & 0.277 & 0.611 & 11.1 & 3.6 \\
\hline & ol & 38.6 & 43.83 & ND & ND & ND & ND & ND & 83.4 & - & - \\
\hline $\begin{array}{l}157-953 \mathrm{C}- \\
97 \mathrm{R}-2,0-16\end{array}$ & & & & & & & & & & & \\
\hline 69 & $\mathrm{gl}$ & 51.08 & 5.64 & 0.95 & 0.017 & 0.137 & ND & 0.220 & 0.495 & - & - \\
\hline & mlt & 51.9 & 7.3 & 0.8 & 0.015 & 0.119 & ND & 0.191 & 0.609 & 0 & 13.3 \\
\hline & $\mathrm{cpx}$ & 51.99 & 17.75 & ND & ND & ND & ND & ND & 0.842 & - & - \\
\hline $157-953 \mathrm{C}-$ & & & & & & & & & & & \\
\hline $\begin{array}{l}\text { 98R-1, 0-12 } \\
44\end{array}$ & g] & 46.72 & 569 & 119 & 0.049 & 0.178 & 0.032 & 0.249 & 0.452 & - & - \\
\hline & mlt & 47.7 & 7.2 & 1 & 0.042 & 0.154 & 0.028 & 0.215 & 0.567 & 0 & 13.4 \\
\hline & $\mathrm{cpx}$ & 48.85 & 15.13 & ND & ND & ND & ND & ND & 0.811 & - & - \\
\hline 51 & gl-1 & 48.67 & 5.38 & 1.33 & 0.020 & 0.187 & 0.022 & 0.279 & 0.462 & - & - \\
\hline & mlt-1 & 49.6 & 7.1 & 1.2 & 0.017 & 0.16 & 0.019 & 0.238 & 0.586 & 0 & 14.4 \\
\hline
\end{tabular}


Table 1 (continued).

\begin{tabular}{|c|c|c|c|c|c|c|c|c|c|c|c|}
\hline Sample & Phase & $\mathrm{SiO}_{2}$ & $\mathrm{MgO}$ & $\mathrm{K}_{2} \mathrm{O}$ & $\mathrm{Cl}$ & $\mathrm{F}$ & S & $\mathrm{P}$ & Mg\#, Fo & $\mathrm{Ol}_{\text {add }}$ & $\mathrm{Cpx}_{\text {add }}$ \\
\hline \multirow{4}{*}{52} & сpx-1 & 50.12 & 16.17 & ND & ND & ND & ND & ND & 0.824 & - & - \\
\hline & $\mathrm{gl}$ & 48.72 & 5.41 & 1.27 & 0.028 & 0.173 & 0.014 & 0.275 & 0.465 & - & \\
\hline & mlt & 49.7 & 7.2 & 1.1 & 0.024 & 0.147 & 0.012 & 0.233 & 0.591 & 0 & 15 \\
\hline & $\operatorname{cpx}$ & 50.15 & 15.96 & ND & ND & ND & ND & ND & 0.828 & - & - \\
\hline \multicolumn{12}{|c|}{ 157-953C- } \\
\hline \multirow{4}{*}{16} & & & & & & & & & & & \\
\hline & gl-1 & 46.63 & 5.9 & 1.26 & 0.022 & 0.171 & 0.018 & 0.286 & 0.469 & - & - \\
\hline & mlt-1 & 47.6 & 6.9 & 1.2 & 0.02 & 0.156 & 0.016 & 0.262 & 0.558 & 0 & 8.4 \\
\hline & cpx-1 & 48.72 & 14.77 & ND & ND & ND & ND & ND & 0.804 & - & - \\
\hline \multirow[t]{3}{*}{$16 \mathrm{~b}$} & gl-2 & 47.14 & 5.62 & 1.44 & 0.026 & 0.166 & 0.016 & 0.316 & 0.465 & - & - \\
\hline & mlt-2 & 48.1 & 6.8 & 1.3 & 0.024 & 0.15 & 0.014 & 0.285 & 0.563 & 0 & 9.9 \\
\hline & cpx-2 & 49.49 & 15.14 & ND & ND & ND & ND & ND & 0.807 & - & - \\
\hline \multirow{3}{*}{32} & gl & 48.71 & 5.28 & 1.49 & 0.022 & 0.165 & 0.068 & 0.306 & 0.445 & - & - \\
\hline & $\begin{array}{l}\text { mlt } \\
\text { mlt }\end{array}$ & 49.6 & 7 & 1.3 & 0.019 & 0.142 & 0.059 & 0.263 & 0.568 & 0 & 13.9 \\
\hline & cpx & 51.03 & 16.34 & ND & ND & ND & ND & ND & 0.812 & - & - \\
\hline \multirow[t]{3}{*}{33} & gl & 46.5 & 6.23 & 1.15 & 0.020 & 0.165 & 0.142 & 0.267 & 0.468 & - & - \\
\hline & mlt & 47.6 & 7.3 & 1.1 & 0.018 & 0.15 & 0.129 & 0.243 & 0.559 & 0 & 9.2 \\
\hline & $\operatorname{cpx}$ & 49.17 & 14.78 & ND & ND & ND & ND & ND & 0.809 & - & - \\
\hline \multirow[t]{3}{*}{34} & $\mathrm{gl}$ & 48.7 & 6.02 & 1.2 & 0.015 & 0.159 & 0.016 & 0.288 & 0.496 & - & - \\
\hline & mlt & 49.4 & 6.9 & 1.1 & 0.014 & 0.148 & 0.015 & 0.267 & 0.579 & 0 & 7.1 \\
\hline & cpx & 49.88 & 15.85 & ND & ND & ND & ND & ND & 0.817 & - & - \\
\hline 157-956B- & & & & & & & & & & & \\
\hline $44 \mathrm{R}-3,57-$ & & & & & & & & & & & \\
\hline 7 & $\mathrm{gl}$ & 48.1 & 4.7 & 1.34 & 0.058 & 0.195 & 0.251 & 0.244 & 0.429 & - & - \\
\hline & mlt & 49.4 & 5.7 & 1.3 & 0.054 & 0.18 & 0.232 & 0.226 & 0.547 & 0 & 7.3 \\
\hline & cpx & 49.03 & 14.77 & ND & ND & ND & ND & ND & 0.785 & - & - \\
\hline $10 \mathrm{~b}$ & $\mathrm{gl}$ & 48.41 & 4.66 & 0.98 & 0.059 & 0.155 & 0.305 & 0.196 & 0.429 & - & - \\
\hline & $\begin{array}{l}\text { mlt } \\
\text { mlt }\end{array}$ & 50.3 & 7.4 & 0.8 & 0.046 & 0.122 & 0.239 & 0.153 & 0.621 & 0 & 21.5 \\
\hline & cpx & 51.31 & 16.33 & ND & ND & ND & ND & ND & 0.847 & - & - \\
\hline 13 & gl & 47.29 & 5.85 & 1.2 & 0.039 & 0.153 & 0.045 & 0.219 & 0.489 & - & - \\
\hline & mlt & 49.2 & 7 & 1.1 & 0.036 & 0.14 & 0.041 & 0.201 & 0.602 & 0 & 8.5 \\
\hline & cpx & 50.24 & 15.87 & ND & ND & ND & ND & ND & 0.832 & - & - \\
\hline 15 & gl & 52.88 & 3.96 & 2.14 & 0.107 & 0.176 & 0.070 & 0.330 & 0.453 & - & - \\
\hline 17 & $\begin{array}{l}\text { mlt } \\
\text { mlt }\end{array}$ & 54.4 & 6.6 & 1.8 & 0.087 & 0.143 & 0.057 & 0.269 & 0.641 & 0 & 18.3 \\
\hline & $\mathrm{cpx}$ & 51.03 & 16.38 & ND & ND & ND & ND & ND & 0.854 & - & - \\
\hline 17 & gl & 47.77 & 4.95 & 1.29 & 0.048 & 0.169 & ND & 0.220 & 0.434 & - & - \\
\hline & mlt & 49.1 & 6 & 1.2 & 0.044 & 0.155 & ND & 0.201 & 0.557 & 0 & 8.5 \\
\hline & cpx & 50.05 & 15.36 & ND & ND & ND & ND & ND & 0.796 & - & - \\
\hline 157-956B- & & & & & & & & & & & \\
\hline $45 \mathrm{R}-3,120$ & & & & & & & & & & & \\
\hline 22 & gl & 49.78 & 5.15 & 1.41 & 0.067 & 0.134 & 0.243 & 0.256 & 0.48 & - & - \\
\hline & mlt & 50.9 & 9 & 1 & 0.048 & 0.095 & 0.173 & 0.182 & 0.701 & 0 & 28.8 \\
\hline & cpx & 52.9 & 17.52 & ND & ND & ND & ND & ND & 0.895 & - & - \\
\hline 23 & gl & 48.65 & 5.18 & 1.07 & 0.025 & 0.095 & 0.032 & 0.150 & 0.476 & - & - \\
\hline 25 & $\begin{array}{l}\text { mlt } \\
\text { mlt }\end{array}$ & 50.4 & 6.7 & 1 & 0.022 & 0.083 & 0.028 & 0.131 & 0.588 & $\overline{0}$ & 12.9 \\
\hline & cpx & 49.36 & 15.33 & ND & ND & ND & ND & ND & 0.825 & - & - \\
\hline 26 & gl & 45.48 & 6.37 & 1.14 & 0.048 & 0.170 & 0.129 & 0.213 & 0.495 & - & - \\
\hline & mlt & 48.2 & 8.1 & 1 & 0.041 & 0.146 & 0.111 & 0.183 & 0.628 & 0 & 14.1 \\
\hline & cpx & 50.69 & 16.19 & ND & ND & ND & ND & ND & 0.855 & - & - \\
\hline $38 \mathrm{~b}$ & gl & 45.22 & 6.03 & 1.04 & 0.051 & 0.166 & 0.192 & 0.208 & 0.46 & - & - \\
\hline & $\mathrm{mlt}$ & 48.1 & 8.7 & 0.8 & 0.04 & 0.13 & 0.15 & 0.162 & 0.636 & 0 & 21.8 \\
\hline & сpx & 51.87 & 16.79 & ND & ND & ND & NI & ND & 0.86 & - & - \\
\hline 52 & gl & 47.24 & 5.32 & 1.56 & 0.051 & 0.180 & 0.057 & 0.283 & 0.46 & - & - \\
\hline & mlt & 49.3 & 6.9 & 1.4 & 0.045 & 0.159 & 0.051 & 0.25 & 0.594 & 0 & 11.5 \\
\hline & сpx & 49.45 & 15.28 & ND & ND & ND & ND & ND & 0.824 & - & 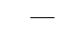 \\
\hline 53 & gl & 45.92 & 5.6 & 1.01 & 0.042 & 0.173 & 0.196 & 0.194 & 0.442 & - & - \\
\hline & $\mathrm{mlt}$ & 48.1 & 7.7 & 0.9 & 0.034 & 0.141 & 0.16 & 0.159 & 0.604 & 0 & 18.2 \\
\hline & cpx & 51.61 & 16.25 & ND & ND & ND & ND & ND & 0.839 & - & - \\
\hline $157-956 \mathrm{~B}$ & & & & & & & & & & & \\
\hline $45 \mathrm{R}-\mathrm{C}$ & & & & & & & & & & & \\
\hline 57 & $\mathrm{gl}$ & $\begin{array}{l}45.2 \\
46.8\end{array}$ & 5.51 & 1.1 & $\begin{array}{l}0.025 \\
0.023\end{array}$ & $\begin{array}{l}0.179 \\
0.168\end{array}$ & $\begin{array}{l}0.054 \\
0.051\end{array}$ & $\begin{array}{l}0.211 \\
0.197\end{array}$ & $\begin{array}{l}0.431 \\
0.538\end{array}$ & $\overline{0}$ & $\overline{6.2}$ \\
\hline & mlt & $\begin{array}{l}46.8 \\
48.5\end{array}$ & $\begin{array}{r}6.3 \\
146\end{array}$ & ND & 0.023 & $\begin{array}{l}0.168 \\
N D\end{array}$ & 0.051 & $\begin{array}{l}0.197 \\
N D\end{array}$ & 0.538 & 0 & 0.2 \\
\hline 58 & $\begin{array}{l}\mathrm{cpx} \\
\mathrm{gl}\end{array}$ & 46.59 & $\begin{array}{r}1.0 \\
4.76\end{array}$ & 1.44 & 0.026 & 0.165 & 0.020 & 0.245 & 0.388 & - & - \\
\hline & mlt & 47. & 6.4 & 1.3 & 0.022 & 0.142 & 0.017 & 0.211 & 0.541 & 0 & 13.7 \\
\hline & cpx & 48.34 & 14.44 & ND & ND & ND & ND & ND & 0.786 & - & . \\
\hline 67 & gl & 51.62 & 4.48 & 1.08 & 0.047 & 0.164 & 0.163 & 0.223 & 0.508 & - & - \\
\hline & mlt & 52.3 & 5.8 & 1 & 0.042 & 0.146 & 0.145 & 0.198 & 0.622 & 0 & 10.9 \\
\hline & cpx & 51.3 & 15.96 & ND & ND & ND & ND & ND & 0.85 & - & - \\
\hline 73 & gl & 46 & 4.53 & 1.52 & 0.035 & 0.183 & 0.026 & 0.271 & 0.375 & - & - \\
\hline & mlt & 46.9 & 5.5 & 1.4 & 0.032 & 0.167 & 0.024 & 0.247 & 0.504 & 0 & 8.6 \\
\hline & cpx & 47.9 & 13.79 & ND & ND & ND & ND & ND & 0.75 & - & - \\
\hline
\end{tabular}

Notes: Sample $=$ sample studied (core, section, interval $[\mathrm{cm}]$, and analyzed grain). $\mathrm{Mg} \#=$ atomic ratio $\mathrm{Mg} /\left(\mathrm{Mg}+\mathrm{Fe}_{\mathrm{tot}}\right)$ in glass inclusions and host clinopyroxenes. Fo $=$ mol $\%$ forsterite in host olivine, $\mathrm{gl}=$ glass (i.e., glass inclusion), mlt = melt (i.e., calculated composition of trapped melt), $\mathrm{Cpx}=$ host clinopyroxene, $\mathrm{Ol}=$ host olivine, $\mathrm{ND}=$ not determined, and $-=$ not calculated. All values are given in weight percent.

Cl, Durango fluorapatite USNM 104021 for F, and basaltic glass USNM 113498/1 (VG-A99) for P, respectively (Jarosewich et al., 1980). The monitor samples used were basaltic glass ALV981R23 for S (Metrich and Clocchiatti, 1989) and comenditic glass KN18 for $\mathrm{F}$ and $\mathrm{Cl}$ (Mosbah et al., 1991). Within each silicate glass inclusion, three to eight spots were measured. Test analyses for $\mathrm{F}, \mathrm{Cl}, \mathrm{S}$, and $\mathrm{P}$ using lower beam currents (10-15 $\mathrm{nA})$ and shorter counting times (20-40 s) were performed on selected inclusions and compositionally similar glasses. When three or more spots per sample were measured, no systematic differences were found between results obtained using the various analytical conditions, except for significant variations in the counting statistics. 
The oxidation state of sulfur dissolved in the glass inclusions was measured through precise determinations of wavelengths for the $S$ $\mathrm{K} \alpha$ peak relative to standards with known sulfur valence states: $\mathrm{BaSO}_{4}$ (barite) was used for calibration of the $\mathrm{S}^{6+} \mathrm{K} \alpha$ peak, and $\mathrm{FeS}$ (pyrrhotite) for $\mathrm{S}^{2-}$ (e.g., Carroll and Rutherford, 1985; Wallace and Carmichael, 1992). Only reduced sulfur $\left(\mathrm{S}^{2-}\right)$ was detected in the inclusions. Detailed results of these studies will be presented elsewhere (J. E. Gardner, unpubl. data).

\section{GLASS INCLUSIONS IN OLIVINE AND CLINOPYROXENE}

\section{Occurrence of Glass Inclusions}

Olivine and clinopyroxene phenocrysts contain (1) inclusions of crystals (inclusions of olivine and plagioclase in clinopyroxene, inclusions of clinopyroxene in olivine, and inclusions of opaque minerals in both olivine and clinopyroxene); (2) glass inclusions (multiphase inclusions of partially crystallized glass, and naturally quenched glass inclusions); and (3) gas/liquid fluid inclusions. Following the classification of Roedder (1984), we subdivide glass, crystal, and fluid inclusions into primary, pseudosecondary, and secondary types. We studied only primary inclusions because they contain direct information on the conditions of magma evolution. Pseudosecondary and secondary inclusions were excluded from further considerations. The investigated primary glass inclusions range in size from 30 to $150 \mu \mathrm{m}$, and either contain glass \pm gas bubble(s), or additionally contain daughter crystals. In one case, a droplet of metal sulfide was found as a primary inclusion in clinopyroxene.

Within a group of presumably syngenetic inclusions, the individual inclusions may range from completely glassy to having a daughter mineral content of several tens of percent. We restricted our measurements to inclusions that are dominated by glass $(>90 \%)$ compared to daughter crystals and do not contain spinel or titanomagnetite daughter crystals. Only inclusions containing optically fresh glass were analyzed. Further inclusion descriptions have been presented by Gurenko et al. (Chap. 22, this volume).

\section{Volatile Contents}

All measurements were performed on naturally quenched glass inclusions in olivine and clinopyroxene. As would be expected for such small systems, variable amounts of host mineral crystallization have occurred on the outer margins of the glass inclusions because of imperfect natural quenching or pre-eruptive cooling within the magma plumbing system. This was detected through low and apparently variable Fe-Mg distribution coefficients between inclusions and host olivine or clinopyroxene (e.g., Roeder and Emslie, 1970), suggesting crystallization of normally zoned mineral rims along the inclusion margins prior to final quenching (Gurenko et al., Chap. 22, this volume). Compositions of the entrapped melts were thus recalculated by adding $0.1 \mathrm{wt} \%$ increments of the inferred momentary equilibrated host mineral composition to the glass inclusions until the $\mathrm{Fe}-\mathrm{Mg}$ equilibrium was reached between the measured host mineral and the recalculated inclusion composition. This correction procedure is described in detail by Gurenko et al. (Chap. 22, this volume).

Concentrations of S, F, Cl, P, and selected major elements for 47 glass inclusions are given in Table 1. (Full major element analyses are given in Gurenko et al., Chap. 22, this volume). Only small variations in $\mathrm{S}, \mathrm{F}, \mathrm{Cl}$, and $\mathrm{P}$ contents were found for inclusions within single crystals. Compositions corrected for host-mineral crystallization are listed in Table 1 and presented in Figures 2, 3, and 4. F and $\mathrm{Cl}$ cover restricted ranges at $1580 \pm 520 \mathrm{ppm}$ and $340 \pm 170 \mathrm{ppm}$, respectively, throughout the entire range of major element compositions (46.3-54.4 wt\% $\mathrm{SiO}_{2}$, and 5.7-10.3 wt\% MgO; Fig. 2). $\mathrm{P}$ and $\mathrm{F}$ show good negative correlations with $\mathrm{MgO}$, suggesting that both el-
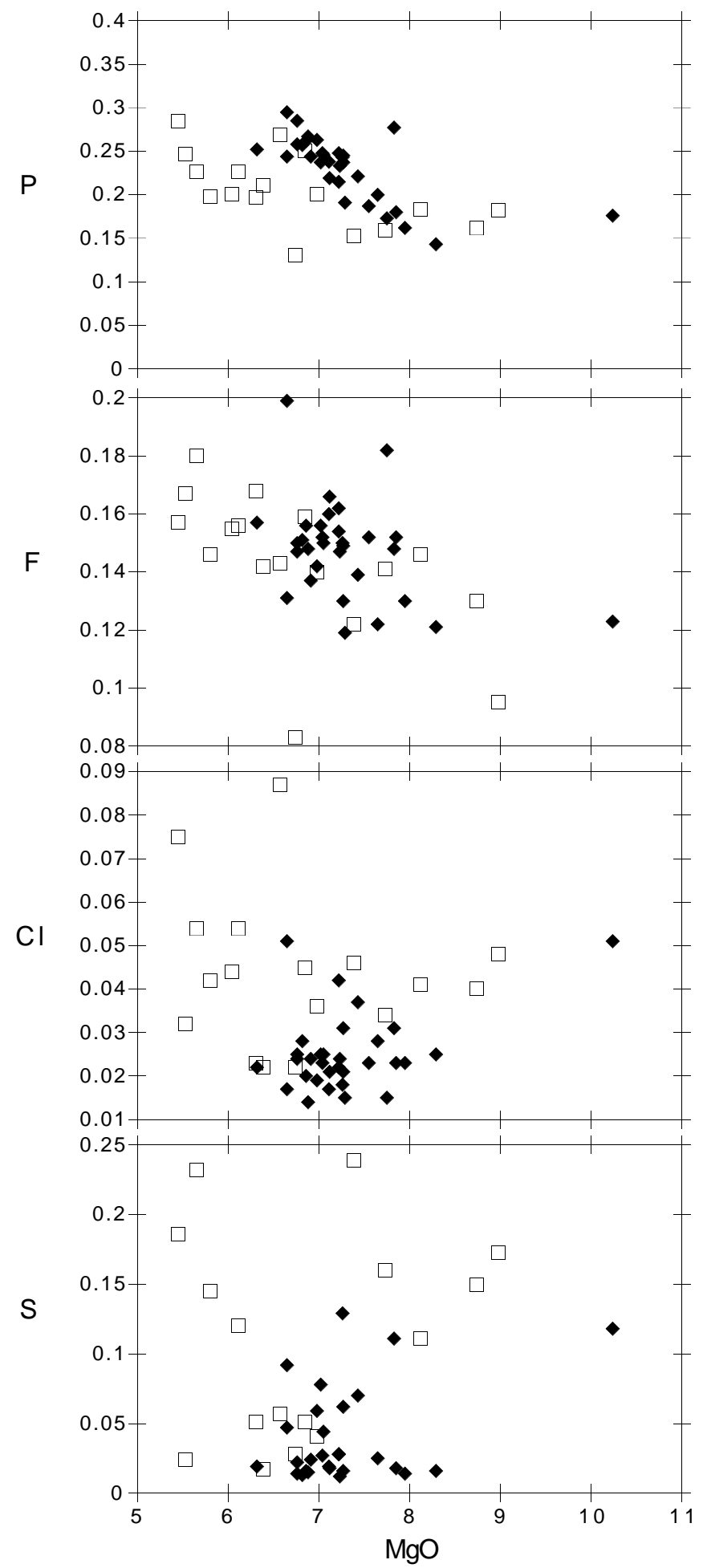

Figure 2. $\mathrm{MgO}$ variation diagrams for the corrected compositions of glass inclusions in olivine and clinopyroxene in Table 1. All values are in weight percent. Legend: Open squares = Site 956, and solid diamonds = Site 953. 


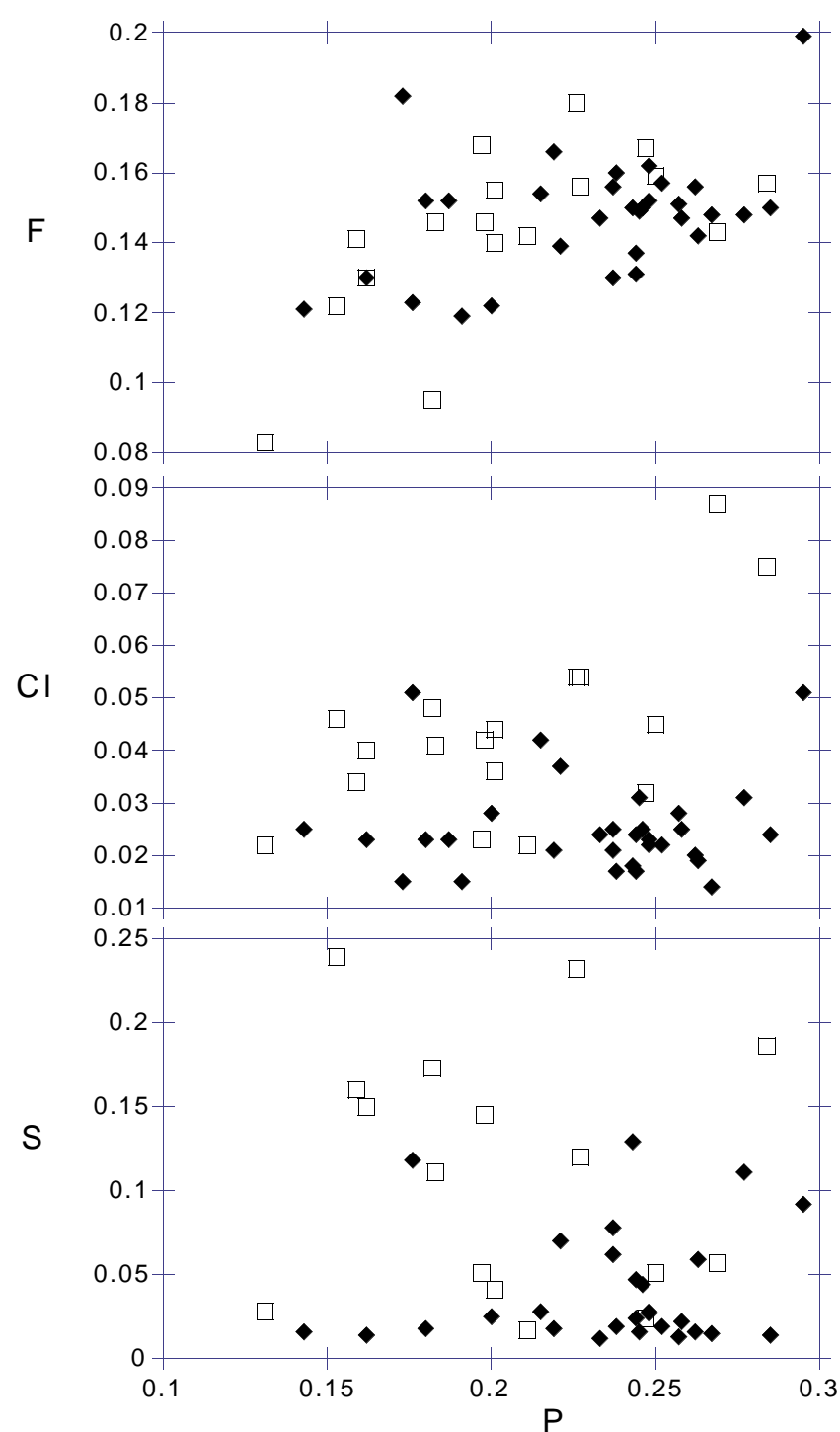

Figure 3. Variation diagrams for the corrected compositions of glass inclusions in olivine and clinopyroxene in Table 1. Legend as in Figure 2.

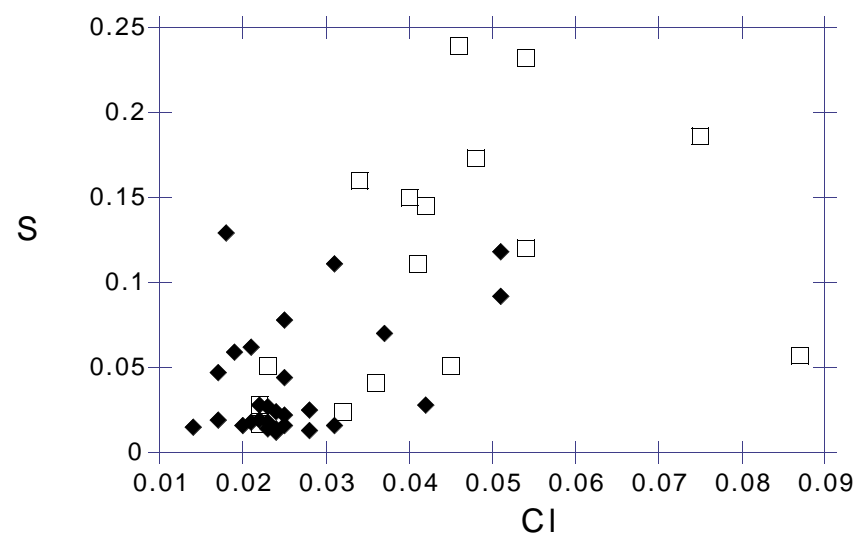

Figure 4. Variation diagrams for the corrected compositions of glass inclusions in olivine and clinopyroxene in Table 1. Legend as in Figure 2. ements have behaved incompatibly and were enriched in the melt during crystal fractionation. S shows considerable scatter over the entire range of $\mathrm{MgO}$, which can be ascribed to either deep-seated degassing or mantle source heterogeneity.

\section{DISCUSSION}

\section{Degassing Upon Magma Evolution}

Concentrations of $\mathrm{S}, \mathrm{F}$, and $\mathrm{Cl}$ were plotted against the incompatible element $\mathrm{P}$ (Fig. 3). Some of the data scatter is probably caused by the relatively high analytical uncertainties at these low concentration levels. The fair correlation between $\mathrm{F}$ and $\mathrm{P}$ (and between $\mathrm{F}$ and $\mathrm{K}$ ) suggests that $\mathrm{F}$ was retained in the melt during crystal fractionation at mantle depths, as was also shown for Pliocene sideromelane glasses at Sites 953, 954, and 956 by Gurenko and Schmincke (Chap. 25, this volume). On the other hand, $\mathrm{Cl}$ and $\mathrm{S}$ show almost no correlation with $\mathrm{P}$, but positive correlation with each other (Figs. 3, 4). Two possible explanations could be suggested for this behavior. First, F was retained almost quantitatively in the liquid during magma ascent and fractional crystallization, and the less soluble elements such as $\mathrm{S}$ and $\mathrm{Cl}$ seem to have been weakly partitioned into the coexisting fluid phase upon early fluid oversaturation, probably at upper mantle depths. This is in partial agreement with experimental and glass inclusion data from basaltic rocks (e.g., Metrich and Clocchiatti, 1989). Because of the higher volatility of $\mathrm{S}$ relative to $\mathrm{Cl}$, the covariation between $\mathrm{S}$ and $\mathrm{Cl}$ may be fortuitous. This is further underlined by the occurrence of sulfide as a primary inclusion in clinopyroxene, suggesting that sulfide saturation was reached upon liquidus evolution for at least some melt batches. Second, an alternative explanation is mantle source heterogeneity and possible differences in the degrees of its partial melting, which can only be traced using volatile elements if the melts were not degassed prior to entrapment in their current host minerals. Source characteristics are discussed below.

The glass inclusions analyzed represent evolved compositions after $10 \%-35 \%$ crystallization from the parental melts (Table 2) within the Gran Canaria magma plumbing system and have been demonstrated to have evolved in crustal and uppermost mantle magma reservoirs (Gurenko et al., 1996, and Chap. 22, this volume). At these levels, degassing may be an important process in basaltic magmas. Because $\mathrm{Cl}$ and $\mathrm{S}$ are more strongly partitioned into a coexisting fluid phase than $\mathrm{F}$, the occurrence of relatively low $\mathrm{Cl}$ and $\mathrm{S}$ concentrations in some of the glass inclusions is likely to reflect shallow lithospheric degassing for these particular melt portions. An important consequence is that the inclusions represent samples of different magma batches, which may have evolved at various depths within the plumbing system. These melts were mixed in reservoirs at shallow lithospheric levels before eruption.

\section{Compositional Variations in the Parental Magmas}

Compositions of parental magmas, which are believed to have been equilibriated with the mantle source, were calculated under the assumption that between partial melting and melt extraction in the source and entrapment of the glass inclusions in phenocrysts, fractional crystallization was the only process operating. This was shown not to be the case for $\mathrm{S}$ and $\mathrm{Cl}$, so their concentrations are regarded as minimum values. Parental magma compositions were calculated by simulating the reverse path of fractional crystallization on the basis of major element compositions of glass inclusions, using a similar calculation routine as that applied for compositional correction of the post-entrapment crystallization in the glass inclusions (Gurenko et al., Chap. 22, this volume). The calculations were carried out in two steps. First, we modeled the reverse path of olivine-clinopyroxene cotectic crystallization until the composition of the calculated melt became equilibrated with the most magnesian clinopyroxene found 
Table 2. Calculated volatile contents of parental magmas.

\begin{tabular}{|c|c|c|c|c|c|c|c|}
\hline Sample & $\mathrm{SiO}_{2}$ & $\mathrm{MgO}$ & $\mathrm{K}_{2} \mathrm{O}$ & $\mathrm{Cl}$ & $\mathrm{F}$ & S & $P$ \\
\hline $\begin{array}{l}157-953 \mathrm{C}- \\
82 \mathrm{R}-1,52-82\end{array}$ & 48.17 & 14.41 & 1.16 & 0.032 & 0.124 & 0.057 & 0.184 \\
\hline $\begin{array}{l}\text { 157-953C- } \\
82 \mathrm{R}-1,94-103\end{array}$ & 47.61 & 15.55 & 0.72 & 0.042 & 0.100 & 0.096 & 0.143 \\
\hline $\begin{array}{l}\text { 157-953C- } \\
\text { 83R-7, 0-12 } \\
\text { Min: } \\
\text { Max: } \\
\text { Mean: }\end{array}$ & $\begin{array}{l}48.16 \\
48.50 \\
48.33\end{array}$ & $\begin{array}{l}17.15 \\
17.12 \\
17.14\end{array}$ & $\begin{array}{l}0.52 \\
0.49 \\
0.51\end{array}$ & $\begin{array}{l}0.017 \\
0.018 \\
0.018\end{array}$ & $\begin{array}{l}0.093 \\
0.090 \\
0.092\end{array}$ & $\begin{array}{l}0.010 \\
0.012 \\
0.011\end{array}$ & $\begin{array}{l}0.115 \\
0.106 \\
0.111\end{array}$ \\
\hline $\begin{array}{l}157-953 \mathrm{C}- \\
89 \mathrm{R}-1,0-13\end{array}$ & 49.07 & 13.84 & 0.67 & 0.020 & 0.086 & 0.018 & 0.141 \\
\hline $\begin{array}{l}\text { 157-953C- } \\
\text { 90R-1, 82-101 } \\
\text { Min: } \\
\text { Max: } \\
\text { Mean: }\end{array}$ & $\begin{array}{l}46.74 \\
47.20 \\
46.93\end{array}$ & $\begin{array}{l}18.04 \\
16.32 \\
17.03\end{array}$ & $\begin{array}{l}0.58 \\
0.59 \\
0.58\end{array}$ & $\begin{array}{l}0.016 \\
0.017 \\
0.015\end{array}$ & $\begin{array}{l}0.103 \\
0.112 \\
0.116\end{array}$ & $\begin{array}{l}0.012 \\
0.012\end{array}$ & $\begin{array}{l}0.122 \\
0.137 \\
0.128\end{array}$ \\
\hline $\begin{array}{l}\text { 157-953C- } \\
\text { 93R-6, 45-55 } \\
\text { Min: } \\
\text { Max: } \\
\text { Mean: }\end{array}$ & $\begin{array}{l}48.02 \\
47.55 \\
48.13\end{array}$ & $\begin{array}{l}15.59 \\
14.48 \\
15.17\end{array}$ & $\begin{array}{l}0.66 \\
0.74 \\
0.70\end{array}$ & $\begin{array}{l}0.011 \\
0.024 \\
0.018\end{array}$ & $\begin{array}{l}0.085 \\
0.117 \\
0.104\end{array}$ & $\begin{array}{l}0.030 \\
0.088 \\
0.030\end{array}$ & $\begin{array}{l}0.159 \\
0.218 \\
0.172\end{array}$ \\
\hline $\begin{array}{l}\text { 157-953C- } \\
97 \mathrm{R}-2,0-16\end{array}$ & 49.95 & 14.75 & 0.65 & 0.012 & 0.092 & & 0.148 \\
\hline $\begin{array}{l}\text { 157-953C- } \\
\text { 98R-1, 0-12 } \\
\text { Min: } \\
\text { Max: } \\
\text { Mean: }\end{array}$ & $\begin{array}{l}46.68 \\
47.97 \\
47.55\end{array}$ & $\begin{array}{l}16.14 \\
15.48 \\
15.71\end{array}$ & $\begin{array}{l}0.74 \\
0.86 \\
0.81\end{array}$ & $\begin{array}{l}0.030 \\
0.013 \\
0.020\end{array}$ & $\begin{array}{l}0.109 \\
0.120 \\
0.113\end{array}$ & $\begin{array}{l}0.020 \\
0.014 \\
0.014\end{array}$ & $\begin{array}{l}0.153 \\
0.178 \\
0.169\end{array}$ \\
\hline $\begin{array}{l}\text { 157-953C- } \\
\text { 102R-1, 8-28 } \\
\text { Min: } \\
\text { Max: } \\
\text { Mean: }\end{array}$ & $\begin{array}{l}48.05 \\
46.90 \\
47.41\end{array}$ & $\begin{array}{l}16.13 \\
15.50 \\
15.59\end{array}$ & $\begin{array}{l}0.91 \\
0.81 \\
0.84\end{array}$ & $\begin{array}{l}0.013 \\
0.014 \\
0.013\end{array}$ & $\begin{array}{l}0.099 \\
0.109 \\
0.105\end{array}$ & $\begin{array}{l}0.041 \\
0.011 \\
0.033\end{array}$ & $\begin{array}{l}0.184 \\
0.182 \\
0.186\end{array}$ \\
\hline $\begin{array}{l}\text { 157-956B- } \\
\text { 44R-3, 57-71 } \\
\text { Min: } \\
\text { Max: } \\
\text { Mean: }\end{array}$ & $\begin{array}{l}49.27 \\
48.99 \\
49.79\end{array}$ & $\begin{array}{l}14.36 \\
14.44 \\
14.11\end{array}$ & $\begin{array}{l}0.57 \\
0.78 \\
0.90\end{array}$ & $\begin{array}{l}0.033 \\
0.033 \\
0.039\end{array}$ & $\begin{array}{l}0.088 \\
0.110 \\
0.101\end{array}$ & $\begin{array}{l}0.172 \\
0.142 \\
0.084\end{array}$ & $\begin{array}{l}0.110 \\
0.138 \\
0.151\end{array}$ \\
\hline $\begin{array}{l}\text { 157-956B- } \\
\text { 45R-3, 120-132 } \\
\text { Min: } \\
\text { Max: } \\
\text { Mean: }\end{array}$ & $\begin{array}{l}50.29 \\
48.93 \\
49.50\end{array}$ & $\begin{array}{l}12.40 \\
13.23 \\
13.29\end{array}$ & $\begin{array}{l}0.65 \\
0.70 \\
0.70\end{array}$ & $\begin{array}{l}0.015 \\
0.028 \\
0.027\end{array}$ & $\begin{array}{l}0.056 \\
0.100 \\
0.085\end{array}$ & $\begin{array}{l}0.019 \\
0.076 \\
0.079\end{array}$ & $\begin{array}{l}0.088 \\
0.125 \\
0.122\end{array}$ \\
\hline $\begin{array}{l}\text { 157-956B- } \\
\text { 45R-CC,7-17 } \\
\text { Min: } \\
\text { Max: } \\
\text { Mean: }\end{array}$ & $\begin{array}{l}47.63 \\
51.04 \\
48.35\end{array}$ & $\begin{array}{l}16.25 \\
11.17 \\
14.69\end{array}$ & $\begin{array}{l}0.74 \\
0.81 \\
0.74\end{array}$ & $\begin{array}{l}0.013 \\
0.034 \\
0.020\end{array}$ & $\begin{array}{l}0.083 \\
0.121 \\
0.099\end{array}$ & $\begin{array}{l}0.010 \\
0.120 \\
0.043\end{array}$ & $\begin{array}{l}0.124 \\
0.164 \\
0.135\end{array}$ \\
\hline
\end{tabular}

Note: Min $=$ minimum, and $\max =$ maximum. All values are in weight percent.

in each particular sample. Second, we modeled reversed fractional crystallization of olivine only, using the melt compositions obtained during the first step. The calculation was ended as soon as the melt reached equilibrium with olivine $\mathrm{Fo}_{90}$, the most magnesian olivine phenocrysts found in Miocene shield basalts of Gran Canaria (Gurenko et al., 1996). Compositions of the calculated parental magmas averaged for each sample are listed in Table 2. It should be noted that calculated parental melt compositions depend strongly on the model used, and on the clinopyroxene composition assumed. The calculated major element data therefore should be treated with care. However, this is not a problem for the incompatible volatile elements, for which the addition of clinopyroxene and olivine to the melts mainly amounts to a dilution.

The average $\mathrm{S}$ concentration estimated for the Gran Canaria primitive magmas is $\sim 500 \mathrm{ppm}$. This average probably represents a minimum value because of partial degassing within holding chambers. This is slightly lower than the $\mathrm{S}$ content of primitive mid-ocean-ridge basalt (MORB) magmas (800-1000 ppm), which is consistent with their formation by $10 \%-20 \%$ partial melting of a mantle source containing 80-300 ppm of S (Chaussidon et al., 1989). The common presence of sulfides in peridotites of mantle origin implies that basaltic magma may form in equilibrium with small but variable amounts of sulfide (Lorand, 1990). Average fractionation-corrected Cl contents are $49 \mathrm{ppm}$ for normal-MORB (N-MORB) and $153 \mathrm{ppm}$ for enriched MORB (E-MORB; Jambon et al., 1995). Our average estimate is $230 \mathrm{ppm} \mathrm{Cl}$ in the primitive magmas, that is, similar but somewhat higher than those of E-MORB. This may point to similar S and halogen contents in the E-MORB source and the source of the Gran Canaria shield stage magmas.

Aoki et al. (1981) noted that a correlation between $\mathrm{K}_{2} \mathrm{O}$ and $\mathrm{F}$ can be used to demonstrate the presence of phlogopite in the source. In Figure 5, no clear correlation exists between $\mathrm{K}_{2} \mathrm{O}$ and F, so phlogopite control in the source cannot be the only explanation for the variable $\mathrm{F}$ concentrations in the Gran Canaria shield magmas. However, Hoernle and Schmincke (1993a, 1993b) found trace element evidence for the presence of phlogopite in the mantle source. A likely scenario would be that the lithospheric mantle beneath Gran Canaria was impregnated with reaction products of deep-seated basaltic magmas prior to the shield-stage volcanism, similar to what has been inferred for several Canary Islands (on the basis of mantle xenolith studies; Neumann, 1991; Hansteen et al., 1991; Neumann et al., 1995). Partial melting of a mantle source metasomatized or enriched in basaltic components, which may contain variable amounts of phlogopite and sulfides \pm amphibole, could possibly explain the scatter in $\mathrm{F}$ and probably, to some extent, $\mathrm{S}$ and $\mathrm{Cl}$ contents in the glass inclusions.

A new generation of experimental studies on partial melting of peridotites indicates that the $\mathrm{SiO}_{2}$ contents of the primary melts are good indicators of the pressure of melting, where low $\mathrm{SiO}_{2}$ contents in partial melts imply higher pressures of magma generation (Hirose and Kushiro, 1993; Hirose and Kawamoto, 1995). $\mathrm{SiO}_{2}$ does not correlate significantly with $\mathrm{F}$ in the calculated parental magmas (Fig. 6). Note that the calculated range in $\mathrm{SiO}_{2}$ for the parental melts (46.7$52.0 \mathrm{wt} \%$ ) reflects a similar range of $\mathrm{SiO}_{2}$ in the inclusions corrected only for post-entrapment crystallization (46.3-54.4 wt\%). When it is assumed that the source is peridotitic, it follows that there is probably little or no depth control on the parental $\mathrm{F}$ (and possibly also $\mathrm{Cl}$ and S) contents. This is in agreement with the model of Gurenko et al. (Chap. 22, this volume). The relative importance of the degrees of partial melting and source heterogeneity on the parental volatile contents cannot be resolved from the present data alone.

\section{Sulfur Speciation and Oxygen Fugacity}

Sulfur may occur in multiple valence states in basaltic liquids (Fincham and Richardson, 1954). Experimental data demonstrate that sulfur solubility in silicate liquids is dependent on temperature, pressure, bulk composition, and the fugacities of oxygen $\left(f_{\mathrm{o}_{2}}\right)$ and sulfur ( $f \mathrm{~s}_{2}$; e.g., Haughton et al., 1974; Luhr, 1990). However, the dissolved $\mathrm{S}$ content in a basic magma does not change significantly as a function of pressure at lithospheric depths (Wallace and Carmichael, 1992). It has also been shown that at magmatic temperatures, $\mathrm{S}$ is present predominantly as sulfide at $f_{\mathrm{O}_{2}}$ more reduced than the fayalite-magnetite-quartz (FMQ) buffer (e.g., Nagashima and Katsura, 1973; Carrol and Rutherford, 1985). The $\mathrm{S}^{6+} / \mathrm{S}_{\text {tot }}$ ratio further correlates positively with $f_{\mathrm{O}_{2}}$ for sulfur-undersaturated melts. For natural basaltic melts, $>90 \%$ of the sulfur occurs as $\mathrm{S}^{2-}$ at $f_{\mathrm{O}_{2}}$ below the Ni$\mathrm{NiO}$ (NNO) buffer (Wallace and Carmichael, 1994).

For the Gran Canaria shield stage magmas, Gurenko et al (Chap. 22 , this volume) have calculated $f_{\mathrm{O}_{2}}$ according to Kilinc et al. (1983), using the equilibrium $\mathrm{Fe}^{2+} / \mathrm{Fe}^{3+}$ ratios in spinel and coexisting glass inclusions (based on experimental data on spinel-silicate melt equilibria of Maurel and Maurel, 1982), major element compositions of the melt, and estimated $\mathrm{T}$ of crystallization. Redox conditions of magma crystallization were calculated at below the FMQ buffer for the early stages of magma evolution, evolving to conditions of NNO \pm 1 during the late stages.

If sulfide saturation is not reached in a basaltic system, the relative contents of $\mathrm{S}^{6+} / \mathrm{S}_{\text {tot }}$ is expected to correlate with $f \mathrm{o}_{2}$. A complication here is that an immiscible sulfide droplet has been found as a primary 


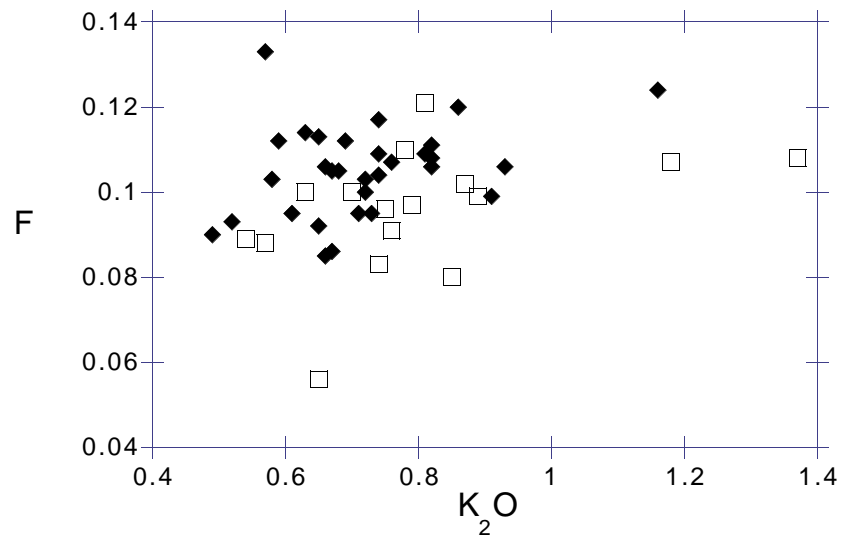

Figure 5. Variation diagrams for the calculated compositions of parental melts in Table 2. Legend as in Figure 2.

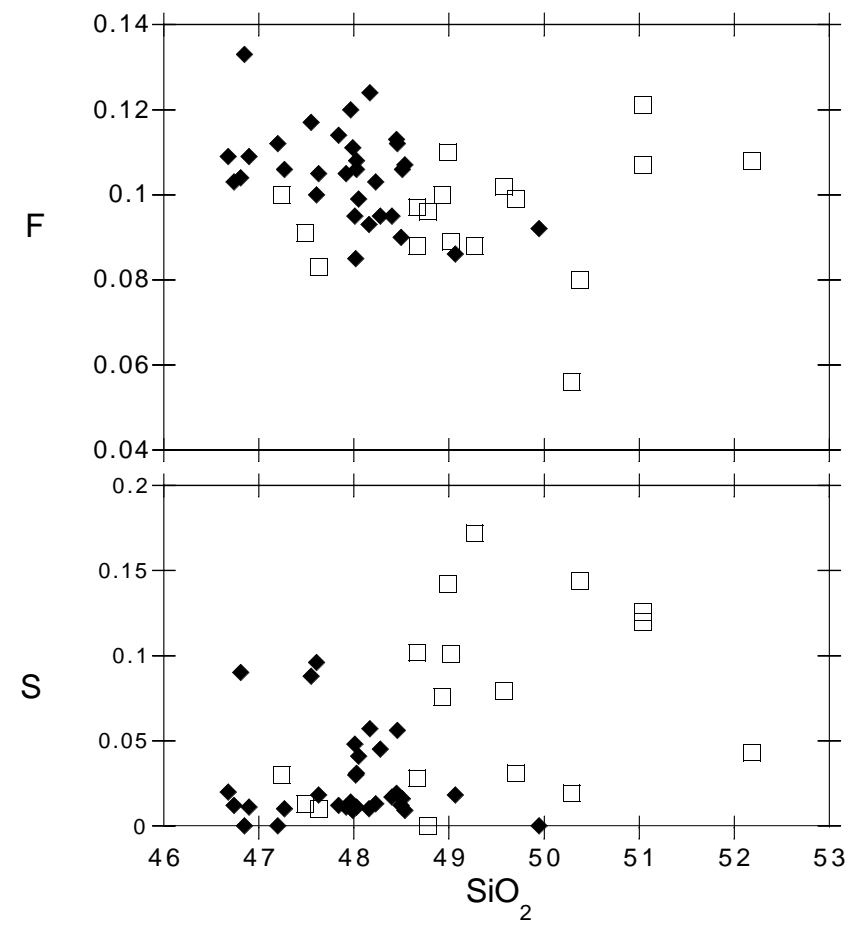

Figure 6. Variation diagrams for the calculated compositions of parental melts in Table 2. Legend as in Figure 2.

inclusion, meaning that sulfide saturation was probably reached for some magma batches during evolution at depth. Although only $\mathrm{S}^{2-}$ was found, the uncertainty of the measurements probably allows for $\sim 10 \%$ of oxidized S species to be present in the glass. However, the occurrence of $\mathrm{S}^{2-}$, as the dominant sulfur species in the Gran Canaria shield phase inclusions, strongly supports an origin of the magmas at $f_{\mathrm{O}_{2}}$ values below the NNO buffer. This is in qualitative agreement with the results of Gurenko et al. (Chap. 22, this volume), which may thus be regarded as maximum values.

\section{CONCLUSIONS}

Silicate glass inclusions in clinopyroxene and olivine from basaltic hyaloclastic tuffs and lapillistones from the Gran Canaria shield stage (Sites 953 and 956) represent several batches of magma evolved under different pressure conditions within the magma plumbing system. Residence of large melt volumes in crustal or upper mantle magma chambers resulted in partial $\mathrm{S}$ and $\mathrm{Cl}$ degassing of some of the magma batches before eruption. F contents in the inclusions have not been significantly affected by degassing, and thus reflect the composition of the mantle source. The occurrence of practically only reduced $\mathrm{S}$ species $\left(\mathrm{S}^{2-}\right)$ in the glass inclusions suggests crystallization at $\mathrm{fO}_{2}$ levels close to or below the NNO buffer.

\section{ACKNOWLEDGMENTS}

This work was supported by grants from the Deutsche Forschungsgemeinschaft HA 2100/2-1 to THH, and an Alexander von Humboldt research fellowship to AAG. Thanks are owed to Hans-Ulrich Schmincke and James E. Gardner for fruitful discussions, and to J.F. Luhr and P.J. Michael for helpful reviews.

\section{REFERENCES}

Aoki, K., Ishikawa, K., and Kanisawa, S., 1981. Fluorine geochemistry of basaltic rocks from continental and oceanic regions and petrogenetic application. Contrib. Mineral. Petrol., 76:53-59.

Carroll, M.R., and Rutherford, M.J., 1985. Sulfide and sulfate saturation in hydrous silicate melts. J. Geophys. Res., 90 (Suppl.):C601-C612.

Chaussidon, M., Albarede, F., and Sheppard, S.M.F., 1989. Sulphur isotope variations in the mantle from ion microprobe analyses of micro-sulphide inclusions. Earth Planet. Sci. Lett., 92:144-156.

Fincham, C.J.B., and Richardson, F.D., 1954. The behaviour of sulfur in silicate and aluminate melts. Proc. R. Soc. London A, 233:40-62.

Funck, T., 1996. Structure of the volcanic apron north of Gran Canaria deduced from reflection seismic, bathymetric and borehole data [Ph.D. dissert.]. Univ. Kiel.

Gurenko, A.A., Hansteen, T.H., and Schmincke H.-U., 1996. Evolution of parental magmas of Miocene shield basalts of Gran Canaria (Canary Islands): constraints from crystal, melt and fluid inclusions in minerals. Contrib. Mineral. Petrol., 124:422-435.

Hansteen, T.H., Andersen, T., Neumann, E.-R., and Jelsma, H., 1991. Fluid and silicate glass inclusions in ultramafic and mafic xenoliths from Hierro, Canary Islands: Implications for mantle metasomatism. Contrib. Mineral. Petrol., 107:242-254

Haughton, D.R., Roeder, P.L., and Skinner, B.J., 1974. Solubility of sulfur in mafic magmas. Econ. Geol., 69:451-467.

Hirose, K., Kawamoto, T., 1995. Hydrous partial melting of lherzolite at 1 GPa: the effect of $\mathrm{H}_{2} \mathrm{O}$ on the genesis of basaltic magmas. Earth Planet. Sci. Lett., 133:463-473

Hirose, K., and Kushiro, I., 1993. Partial melting of dry peridotites at high pressures: determination of compositions of melts segregated from peridotite using aggregates of diamond. Earth Planet. Sci. Lett., 114:477489.

Hoernle, K., and Schmincke, H.-U., 1993a. The petrology of the tholeiites through melilite nephelinites on Gran Canaria, Canary Islands: crystal fractionation, accumulation, and depth of melting. J. Petrol., 34:573-578. , 1993b. The role of partial melting in the 15-Ma geochemical evolution of Gran Canaria: a blob model for the Canary Hotspot. J. Petrol., 34:599-627.

Jambon, A., Déruelle, B., Dreibus, G., and Pineau, F., 1995. Chlorine and bromine abundance in MORB: the contrasting behaviour of the MidAtlantic Ridge and East Pacific Rise and implications for chlorine geodynamic cycle. Chem. Geol., 126:101-117.

Jarosewich, E., Nelen, J.A., and Norberg, J.A., 1980. Reference samples for electron microprobe analysis. Geostand. Newsl., 4:43-47.

Kilinc, A., Carmichael, I.S.E., Rivers, M.L., and Sack, R.O., 1983. The ferric-ferrous ratio of natural silicate liquids equilibrated in air. Contrib. Mineral. Petrol., 83:136-140.

Lorand, J.P., 1990. Are spinel lherzolite xenoliths representative of the abundance of sulfur in the upper mantle? Geochim. Cosmochim. Acta, 54:1487-1492.

Luhr, J.F., 1990. Experimental phase relations of water- and sulfur-saturated arc magmas and the 1982 eruptions of El Chichón volcano. J. Petrol., 31:1071-1114. 
Maurel, C., and Maurel, P., 1982. Etude expérimentale de l'équilibre $\mathrm{Fe}^{2+}$ $\mathrm{Fe}^{3+}$ dans les spinelles chromifères et les liquides silicatés basiques coexistants, à $1 \mathrm{~atm}$. C.R. Acad. Sci. Paris, 285:209-215.

Metrich, N., and Clocchiatti, C., 1989. Melt inclusion investigation of the volatile behaviour in historic alkali basaltic magmas of Etna. Bull. Volcanol., 51:185-198.

Mosbah, M., Metrich, N. and Massiot, P., 1991. PIGME fluorine determination using a nuclear microprobe with application to glass inclusions. Nucl. Instr. Meth. Phys. Res., B58:227-231.

Nagashima, S., and Katsura, T., 1973. The solubility of sulfur in $\mathrm{Na}_{2} \mathrm{O}-\mathrm{SiO}_{2}$ melts under various oxygen partial pressures at 1100,1250 and $1300{ }^{\circ} \mathrm{C}$. Bull. Chem. Soc. Jpn., 46:3099-3103.

Neumann, E.-R., 1991. Ultramafic and mafic xenoliths from Hierro, Canary Islands: evidence for melt infiltration in the upper mantle. Contrib. Mineral. Petrol., 106:236-252.

Neumann, E.-R., Wulff-Pedersen, E., Johnsen, K., Andersen, T., and Krogh, E., 1995. Petrogenesis of spinel harzburgite and dunite suite xenoliths from Lanzarote, eastern Canary Islands: implications for the upper mantle. Lithos, 35:83-107.
Roedder, E., 1984. Fluid inclusions. Rev. Mineral., Mineral. Soc. Am., 12.

Roeder, P.L., and Emslie, R.F., 1970. Olivine-liquid equilibrium. Contrib. Mineral. Petrol., 29:275-289.

Schmincke, H.-U., Weaver, P.P.E., and Firth, J., 1995. The clastic apron of Gran Canaria and the Madeira Abyssal Plain. JOIDES J., 21:14-22.

Schmincke, H.-U., Weaver, P.P.E., Firth, J.V., et al., 1995. Proc. ODP, Init. Repts., 157: College Station, TX (Ocean Drilling Program).

Wallace, P., and Carmichael, I.S.E., 1992. Sulfur in basaltic magmas. Geochim. Cosmochim. Acta, 56:1863-1874.

, 1994. S speciation in submarine basaltic glasses as determined by measurements of S K $\alpha$ X-ray wavelength shift. Am. Mineral., 79:161167.

Date of initial receipt: 3 June 1996

Date of acceptance: 6 January 1997

Ms 157SR-139 